\section{第 7 群}

\section{4 顔面神経管病変を伴う慢性中耳炎について}

○森 弘, 淈内政子, 北原一明, 服部康夫 (北野病院)
私どる，1968〜 1973年の 6 年間に慢性中耳炎 772 例

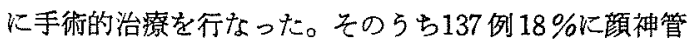
病変を伴っていたため中耳炎手術時に顔神管開放術を合 せ行なった。周知のごとく，耳性脳膜炎が減少している にかかわらず，顏神管病変を伴う中耳炎が多数認められ ることは，最近の中耳炎の病態として注目すべと考

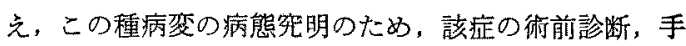
術所見, 病栄肉芽の組的所学見, 予後などについて述 ベる。

われわれは，現在，聴神経腫瘳にたいして経迷路的 (症例により後頭蓋窝法を併用) フプローチをルーチン に扣こなっている。その場合，内耳道内の腫湯を完全に 摘出するのみならす顔面神経の保存に一層の注意がはら わなければならない。

腫演の小さい症例でも内耳道内の腫癔の充满は著明 で, 内耳道底方向への進展の度合が顔面神経保存の重要 な鍵となる。

低温時に起こる細胞の障害の発生機序は, cryobiology に括ける重要な研究課題の一つである。われわれは内耳 有毛細胞の生体内括よび生体外に批けるエネルギー代謝 を，Nitro-BT を含む反応液を用いることにより，組織 化学的に観察しうることを明かにした。今回は，この方 法を用いて，モルモットのラセン器及び前庭器の有毛細 胞に赫けるェネルギー代謝に及ぼす低温の影響を検索 し，低温により細胞内代謝が著しく障害されることを知 った。

最近は穿孔性中耳炎は減少してきたが，非穿孔性のむ のが增加してきた。そして非穿孔性中耳炎といわれるる のの病態はいろいろである。そこでそれらの病態の把握 と，それらの発生および経過について述べる。また中耳 炎のもう一つの問題である中耳真珠腫の発生形態がどの ように变貌したかを示すとともに，今日に特汓る真珠腫 形成についての新しい問題を提示し，中耳真珠腫の発生 に出いての病態がどのような変貌をしつつあるかを論ず る。 